\title{
Ojibwe Language
}

National Cancer Institute

\section{Source}

National Cancer Institute. Ojibwe Language. NCI Thesaurus. Code C154068.

An indigenous language in the Algonquian language family spoken by the Ojubwe people in Canada and the United States. 